pp. 53-63

\title{
The Empirical Relationship between Corporate Social Responsibility Advantage (CSRA) and Organizational Performance: Moderating Effects of Entrepreneurship Orientation in Thailand
}

\author{
Submitted 11/05/21, 1st revision 28/06/21, 2nd revision 20/07/21, accepted 10/08/21
}

\begin{abstract}
Nirusa Sirivariskul ${ }^{1}$
Abstract:

Purpose: This research aimed to examine the influence of Corporate Social Responsibility Advantage (CSRA) to organization performance which focused on the moderating role of entrepreneurship orientation in the relationship among collaborative network, managerial innovation and organizational performance.

Design/Methodology/Approach: A survey questionnaire was used to collect data from 54 firms in Corporate Social Responsibility Department of Industrial Work (CSR-DIW) of Thailand. This study tests hypotheses using hierarchical regression analysis.

Findings: The results make contributions to the management literature ndicating that under CSRA such as collaborative network and managerial innovation the interaction with entrepreneurship orientation had a positive influence on organization performance.

Practical Implications: Evidence to support the moderating effects provides a discussion on the academics and practitioners for future research. This research provided reasons that firms would be able to take advantage from CSR such as collaborative network and managerial innovation, in terms of knowledge that may encourage a new process which is positive to organization's strategy, structure, administrative procedures and systems.

Originality/Value: This paper focus the impact of CSRA on the organizational performance under entrepreneurship orientation as moderator of CSR-DIW in Thailand. The results will be important for understanding the role of CSRA in a firm's adaptation to entrepreneurship orientation. CSRA is now widely implemented in many companies because CSRA development should be continually developed and coupled with entrepreneurship orientation, it is necessary to nurture the CSRA attitude of companies, which is more oriented on honesty (awareness to the quality improvement of stakeholders such as employees' life and their families, local communities and a broad society, the willingness to take CSRA as an important factor for entrepreneurs' success.
\end{abstract}

Keywords: CSRA, organizational performance, entrepreneurship orientation, collaborative network, managerial innovation.

JEL codes: D21, D22.

Paper type: Research article

\footnotetext{
${ }^{1}$ Faculty of Science and Social Science, Burapha University, Thailand E-mail: $\underline{\text { Chonticha_m@buu.ac.th }}$
} 


\section{Introduction}

In recent years, Corporate Social Responsibility (CSR) topic has received increasing attention in fields of the economic research and practical management. CSR is a concept associated with several topics such as corporate social performance and corporate sustainability (Blowfield and Murray, 2008; Carrol and Shabana, 2010). CSR has also been defined in many terms. The European Commission has defined CSR as 'concept whereby companies integrate social and environmental concerns in their business operations and in their interactions with their stakeholders on a voluntary bias' (Commission of European, 2006. Some scholars give CSR definition as 'a firm's commitment to maximize long-term economic, social and environmental well-being through business practices, policies and resources' (Du and Vieira, 2012).

Interestingly, corporate social responsibility (CSR) orientation is the key to stimulate long-term stability, growth and sustainable performance in the management literature (Luo and Homburg, 2007; Prado-Lorenzo et al., 2008; Jalilvand et al., 2017). CSR practices can be voluntary firm actions to improve social or environmental conditions (Mackey et al., 2007). In fact, CSR has interaction with several CSR-related variables, such as entrepreneurship, collaboration and innovation. However, some studies showed ambiguous results of examining consequence of CSR. Gallego Alvarez et al., (2011) explained that firms focus on CSR as an important strategy for promoting entrepreneurial culture. Previous studies have proved the relationship of CSR on innovation and entrepreneurship which demonstrating that CSR can influence on innovation and entrepreneurial orientation (Tuan, 2015; Holt, 2012; Dacin et al., 2010).

Besides, the academic literature of collaboration and CSR has concerned with potential advantage to the collaborative organizations in societal benefit. The collaboration has many terms such as "partnership", "cooperation", "alliance", "coalition", which integrate to achieve a goal within a collaborative indenture. The form of collaboration is a type of inter-organizational relationship and refers to "working across organizational boundaries towards some positive end" (Huxham and Vangen, 2005). Many dimensions within a collaboration have related to resources, degree of trust, and structure. However, Martınez-Sanchez et al., (2009) suggested that the benefit of intra-organizational cooperation is knowledge in processes and products lead to internal and external flexibility and innovation. Thus, managerial innovation is a new approach to knowledge for work of management which leads to strategy, structure, administrative procedures and systems. Bansal (2005) and Husted and Allen (2007) suggested that the use of social, environmental or sustainability to link between CSR practices and innovation strategies, through drivers can create new products, services, processes and new market. The study of MacGregor and Fontrodona (2008) focusing on companies in Spain, Italy and the UK to find a link between the CSR-innovation relationship, has found that CSR and innovation are driven together. 
Based on the previous back ground, this research aim to study the relationship of corporate social responsibility advantage (CSRA) and organizational performance, which focused on the moderating role of entrepreneurship orientation in the relationship among collaborative network, managerial innovation and organizational performance which found in the gap of academic literature. The main objective of this research was to investigate the firms that achieved its CSR goals which continuous commitment to CSR and gained CSR-DIW award from Corporate Social Responsibility Department of Industrial Work (CSR-DIW) in Thailand. Corporate Social Responsibility Department of Industrial Work (CSR-DIW) is a division of Thailand's government to develop the potential of Corporate Social Responsibility. The CSR-DIW awards program stands for Corporate Social Responsibility and is organized by the Department of Industrial Work (Ministry of Industry) which gives the awards to companies which have participated in and successfully passed the stringent conditions and requirements of each award following the department information transfer and auditing processes. The awards recognize companies that have shown continuous commitment to CSR in seven major criteria including, corporate governance, human rights, labor practices, environment, fair operation, consumer issues and community services.

This research used hierarchical regression analysis to test those relationships. The research methodology was presented, and a detailed description of data and analysis was provided. The next section presents the research findings and discussion. The last section provides limitations and suggestions for further research and a few recommendations that might help promote CSR practices in organizations. Thus, this research expected that CSRA will guide firms toward entrepreneurial activities to satisfy the expectations of stakeholders. Hence, the following hypothesis arises:

H1a: CSR is positively associated with collaborative network.

$H 1 b$ : CSR is positively associated with managerial innovation.

H2a: Collaborative network is positively associated with organizational performance.

$H 2 b$ : Managerial innovation is positively associated with organizational performance.

H3a: Entrepreneurship orientation negatively moderated the relationship between collaborative network and organizational performance.

$H 3 b$ : Entrepreneurship orientation positively moderated the relationship between managerial innovation and organizational performance.

\section{Research Method}

This study was conducted using data collected from entrepreneurs who were registered in Corporate Social Responsibility, Department of Industrial Works (CSR-DIW) of Thailand. Corporate Social Responsibility, Department of Industrial 
Works (CSR-DIW) as a corporation which focused on the importance of "Corporate Social Responsibility" to consistently preserve society while creating sustainable public well-being in surrounding communities. Mail survey was used for data collection and sent to 270 manufacturing industries. A cover letter, stamped reply envelope and copies of the questionnaire were sent to chief executive officers (CEO)'s, directing managers or general manager in a sample. A total of 270 surveys were received and54 usable responses resulted in response rates of 20. Furthermore, a test for non-response bias (Armstrong and Overton, 1977) in mail surveys was assessed by comparing between earliest and latest response is used.

\section{Research Results}

To test the research framework as shown in Figure 1, the study first analyzed the reliability and validity of the data as shown in Table 1 . Composite reliability was assessed by Cronbach's alpha to verify the inter-item consistencies (Nunnally, 1978). A reliability coefficient of 0.7 for each variable shown in Table 1 suggests that the theoretical constructs exhibit good psychometric properties. Discriminant validity of the scale assessed by average variance extracted (AVE) is shown in Table 1 , which is above 0.5 and the square root of the AVE for each construct are significantly greater than the off-diagonal elements.

Common method bias exists when the measurement technique introduced systematic variance into the measures (Doty and Glick, 1998). In addition, the Corrected itemtotal Correlation (CITC) was used for reliability test (Kerlinger, 1986). The Corrected Item-total Correlation (CITC) of each measure was above the suggested cut off of 0.30. Results in Table 1 show that all CITC values were larger than 0.40, which was sufficient for confirming level of reliability in research (Nunnally, 1978; Churchill and Iacobucci, 2002).

This study used linear hierarchical regression analysis to test the hypothesized relationships (Table 2). Table 2 provides the descriptive statistics and zero-order correlations among the variables used in the regression analyses. Models 1 and 2 have supported both hypotheses. In particular, the coefficient for relationship between Corporate Social Responsibility and collaborative network is found to be highly significant at the 0.001 level $(\beta=0.702)$, likewise the relation involving managerial innovation is also significant at the 0.001 level $(\beta=0.661)$, in support of Hypothesis H1a and H1b. In Model 3, the independent variables added in model which was $60.7 \%$ of the variation in organizational performance. Meanwhile, collaborative network and managerial innovation relates positively to organizational performance but not significantly $\left(\beta_{\text {collaborative network }}=0.117, p>0.05 ; \beta_{\text {managerial innovation }}\right.$ $=0.113, \mathrm{p}>0.05$, respectively). Thus, results did not support both $\mathrm{H} 2 \mathrm{a}$ and $\mathrm{H} 2 \mathrm{~b}$.

Model 4 tests the moderating effect of entrepreneurship orientation (two-way interaction) for $\mathrm{H} 3 \mathrm{a}$ and $\mathrm{H} 3 \mathrm{~b}$. The results of the moderated regression analysis are significant for both collaborative network and managerial innovation. Model 4 
significantly increased which explained variance (Adjusted $R^{2}=0.635$ ). Model 4 also shows entrepreneurship orientation negatively $\left(\beta_{\text {collaborative network } x \text { entrepreneurship }}\right.$ orientation $=-0.386, \mathrm{p}<0.05)$ and positively $\left(\beta_{\text {managerial innovation } \mathrm{x} \text { entrepreneurship orientation }}=0.338\right.$, $\mathrm{p}<0.05)$ moderated the interactive effect of collaborative network and managerial innovation on organizational performance, respectively. Thus, $\mathrm{H} 3 \mathrm{a}$ and $\mathrm{H} 3 \mathrm{~b}$ that predicted two-way interactions of entrepreneurship orientation were supported. Comparison of these 4 models, indicated that $\mathrm{R}^{2}$ increases in each step of the hierarchical analysis, suggesting the direct effects of independent variables (Cohen et al., 1983).

Table 1. Correlations and descriptive statistics

\begin{tabular}{|c|c|c|c|c|c|c|c|c|c|c|c|}
\hline \multirow[b]{2}{*}{ Variables } & \multirow{2}{*}{$\begin{array}{l}\text { No } \\
\text { of } \\
\text { item } \\
S\end{array}$} & \multirow{2}{*}{$\begin{array}{l}\text { CITC range } \\
\text { of the } \\
\text { underlying } \\
\text { items }\end{array}$} & \multirow{2}{*}{$\begin{array}{l}\text { Factor } \\
\text { Loadings }\end{array}$} & \multirow[b]{2}{*}{$\alpha$} & \multirow[b]{2}{*}{ CR } & \multirow[b]{2}{*}{ AVE } & \multicolumn{5}{|c|}{ Constructs } \\
\hline & & & & & & & CSR & $\mathrm{CN}$ & MIL & EO & OP \\
\hline $\begin{array}{l}\text { Corporate Social } \\
\text { Responsibility }\end{array}$ & 5 & $0.450-0.771$ & $0.605-0.882$ & 0.832 & 0.900 & 0.645 & 0.803 & & & & \\
\hline $\begin{array}{l}\text { Collaborative } \\
\text { Network }\end{array}$ & 3 & $0.624-0.689$ & $0.836-0.837$ & 0.789 & 0.883 & 0.730 & $.681^{* *}$ & 0.854 & & & \\
\hline $\begin{array}{l}\text { Entrepreneurship } \\
\text { Orientation }\end{array}$ & 7 & $0.599-0.884$ & $0.702-0.923$ & 0.911 & 0.932 & 0.663 & $.468^{* *}$ & $.552^{* *}$ & $.524^{*}$ & 0.814 & \\
\hline $\begin{array}{l}\text { Organizational } \\
\text { Performance }\end{array}$ & 5 & $0.476-0.726$ & $0.639-0.843$ & 0.823 & 0.877 & 0.589 & $.451^{* *}$ & $.540^{* *}$ & $.572^{*}$ & $.768^{*}$ & 0.768 \\
\hline
\end{tabular}

Notes: $* *$ Correlation is significant at the 0.01 level $(2$-tailed). Main diagonal $=\sqrt{A V E}$

Source: Own study.

Figure 1. Research Framework

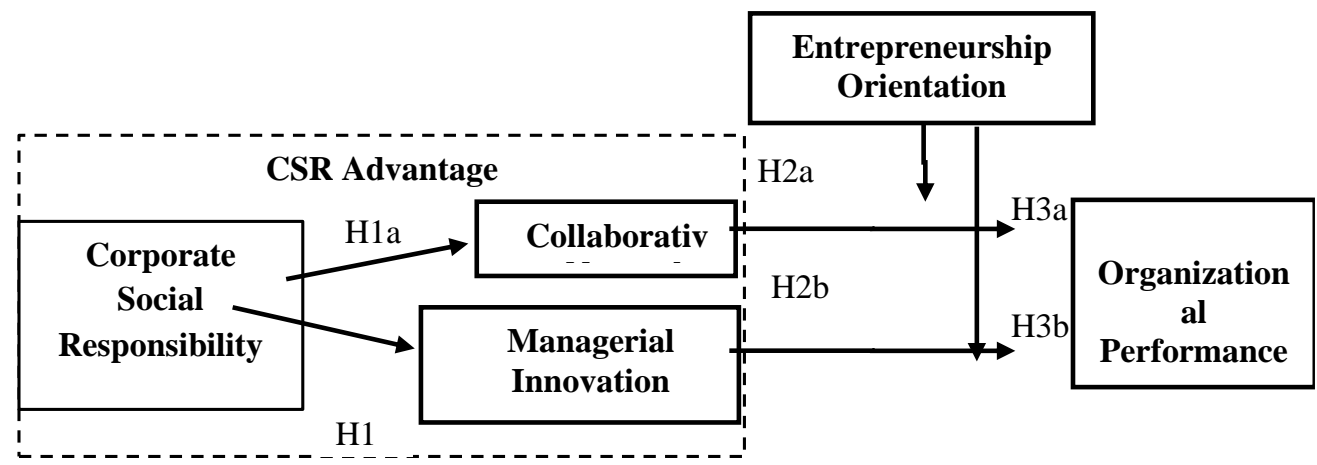

Source: Own study. 
The Empirical Relationship between CSRA and Organizational Performance: Moderating Effects of Entrepreneurship Orientation in Thailand

Table 2. Results of hierarchical moderated regression models

\begin{tabular}{|c|c|c|c|c|c|}
\hline \multirow[t]{3}{*}{ Variables } & \multicolumn{3}{|c|}{ Standard Coefficient } & & \\
\hline & \multirow{2}{*}{ CN } & \multirow{2}{*}{$\begin{array}{l}\text { MI } \\
\text { Step 2 }\end{array}$} & \multicolumn{3}{|c|}{ Organizational Performance (OP) } \\
\hline & & & Step 3 & Step 4 & Outcome \\
\hline Control variable: & & & & & \\
\hline Firm Size & -0.041 & 0.013 & -0.09 & -0.086 & \\
\hline Independent variables: & $0.702^{* * *}$ & $0.661^{* * *}$ & & & \\
\hline $\begin{array}{l}\text { Corporate Social Responsibility } \\
\text { (CSR) }\end{array}$ & & & & & $\begin{array}{l}\text { Supported } \\
\text { H1b : } \\
\text { Supported }\end{array}$ \\
\hline Collaborative Network (CN) & & & 0.117 & 0.042 & $\mathrm{H} 2 \mathrm{a}$ : Not \\
\hline Managerial Innovation (MI) & & & 0.113 & 0.114 & $\begin{array}{l}\mathrm{H} 2 \mathrm{~b}: \text { Not } \\
\text { Supported }\end{array}$ \\
\hline $\begin{array}{l}\text { Entrepreneurship } \text { Orientation } \\
\text { (EO) }\end{array}$ & & & 0.661 & 0.735 & \\
\hline Interaction terms: & & & & & \\
\hline Collaborative Network* EO & & & & $-0.386^{*}$ & $\begin{array}{l}\text { H3a : } \\
\text { Supported }\end{array}$ \\
\hline Managerial Innovation*EO & & & & $0.338^{*}$ & $\begin{array}{l}\text { H3b : } \\
\text { Supported }\end{array}$ \\
\hline Model summary & $52501^{* * * *}$ & $30502 * * *$ & $1502^{* * * * *}$ & $16250^{* * * *}$ & \\
\hline $\begin{array}{l}\mathrm{F} \\
\mathrm{R}^{2}\end{array}$ & $\begin{array}{r}22.001 \\
0.469\end{array}$ & $\begin{array}{r}20.003 \\
0.446\end{array}$ & 0.637 & $\begin{array}{r}10.030 \\
0.676\end{array}$ & \\
\hline Adjusted $\mathrm{R}^{2}$ & 0.448 & 0.424 & 0.607 & 0.635 & \\
\hline
\end{tabular}

Note: *Sign. at the 0.05 level, **Sign. at the 0.01 level, ***Sign. at the 0.001 level.

Source: Own study.

Figure 2. Moderating effects of entrepreneurship orientation on relationship between collaborative network and organizational performance

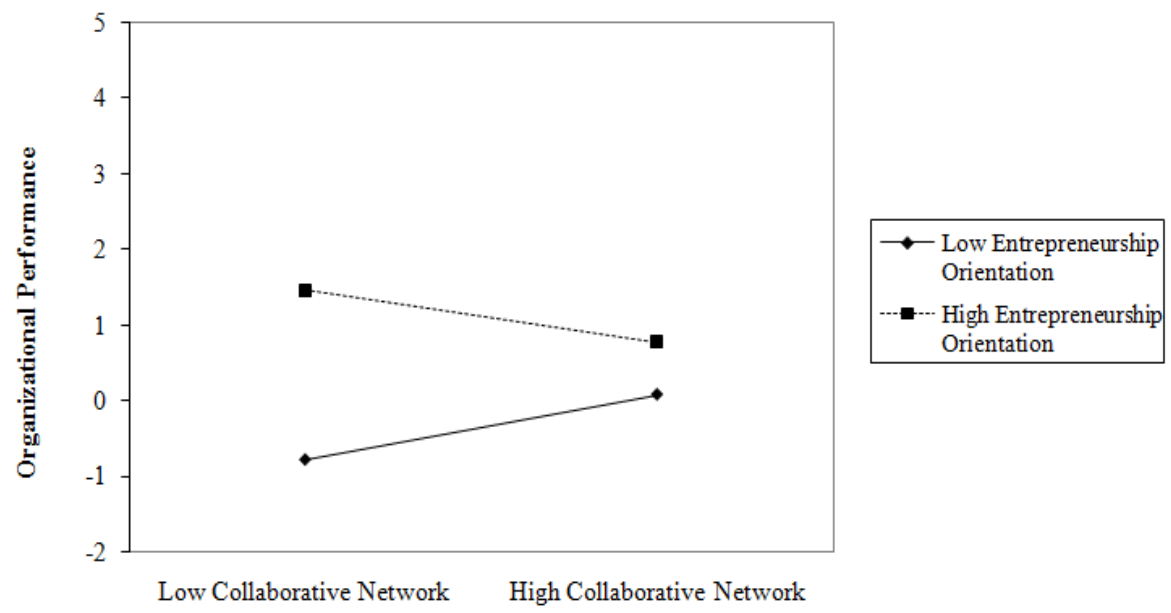

Source: Own study. 
Figure 3. Moderating effects of entrepreneurship orientation on relationship between managerial innovation and organizational performance

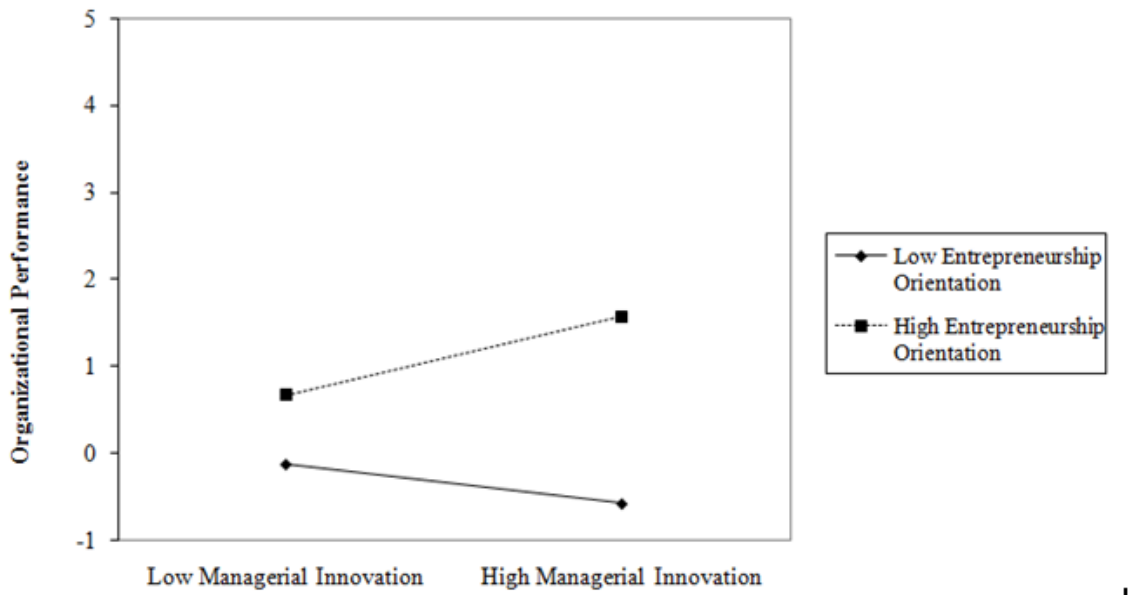

Source: Own study.

\section{Discussion}

This study examined the relationship between CSRA and organizational performance and moderating effect of entrepreneurship orientation in Thailand. This study was conducted in the context of the companies, the firm that achieved its CSR goals which have shown continuous commitment to CSR and gained CSR-DIW award from Corporate Social Responsibility Department of Industrial Work (CSRDIW) in Thailand.

The results showed that Corporate Social Responsibility (CSR) has positive effect on collaborative network (H1a) and managerial innovation (H1b). The coefficients for collaborative network and managerial innovation have no significance on organizational performance $(\mathrm{H} 2 \mathrm{a}, \mathrm{H} 2 \mathrm{~b})$. Entrepreneurship orientation negatively moderated the relationship between collaborative network and organizational performance (H3a) and considered entrepreneurship orientation positively moderated the relationship between managerial innovation and organizational performance $(\mathrm{H} 3 b)$.

Figure 1 suggests that under low levels of entrepreneurship orientation, firms with higher levels of collaborative network would perform better than those with lower levels of collaborative network. In contrast, when the entrepreneurship orientation level is high, the performance of the firms is found to be negatively associated with the levels of collaborative network. While entrepreneurship orientation's modulating effects are found to be negative, Figure 2 shows that the moderating effects are positive. Although managerial innovation is found to be positively linked to performance under both high and low levels of entrepreneurship orientation, the slope for the high levels of entrepreneurship orientation is steeper than that for the 
low levels of entrepreneurship orientation, suggesting the contribution of managerial innovation to business performance would increase with the levels of entrepreneurship orientation. These findings of results make contributions to the literature. The findings have implications in understanding of the role of corporate social responsibility advantage in a firm's adaptation to entrepreneurship orientation. CSR is now widely implemented in many companies.

Firstly, this research model is focusing on of advantage of CSR which leads to collaborative network and managerial innovation. Corporate social responsibility (CSR) is the key importance to stimulate growth and sustainable performance (Jalilvand et al., 2017). The corporate strategy of many companies, considered CSR as an important for achieving a competitive advantage (Kim et al., 2012). As the research results showed, as CSR fosters collaborative network and managerial innovation, CSR initiatives should be created and implemented toward sustainable actions such as collaborative network which leads to the intent to survive and achieve mutual benefits. The collaborative advantage goal is to build multiple organizations together to achieve something that individual organizations could not achieve alone (Huxham, 2003). The results of this study also showed that CSR had positive effect on managerial innovation which is consistent with Vilanova, Lozano and Arenas (2009) who analyzed the top 25 most innovative companies and realized that most of them had strong commitment to CSR.

Secondly, empirical results showed that corporate social responsibility advantage (CSRA) did not significantly impact organizational performance. The global research attention in CSR topic over the years indicated that CSR has significantly impacted on organizational performance (OP) (López-Arceiz, Bellostas-Pérezgrueso, Moneva Abadía, and Rivera-Torres, 2018; Miras Rodriguez, Carrasco Gallego, and Escobar Perez, 2014). However, some studies examining the direct relationship between CSR and organizational performance have provided inconclusive and ambiguous results (Mishra and Suar, 2010; Oeyono, Samy, and Bampton, 2011). This research provided reasons that firms would be able to take advantage from CSR such as collaborative network and managerial innovation, in terms of knowledge that may encourage a new processes which is positive to organization's strategy, structure, administrative procedures and systems.

Thirdly, the moderating role of entrepreneurship orientation for the relationship between collaborative network, managerial innovation and organizational performance, provided the interesting results of the study which was the significant interaction between collaborative network, managerial innovation with entrepreneurship orientation. Although, corporate social responsibility advantage (CSRA) such as collaborative network and managerial innovation may not be adequate for organizational performance. Entrepreneurship orientation has potential for assisting researchers and organizations to understand how firms adapt to complex and turbulent environments. 
Accordingly, it can be argued that entrepreneurship orientation is strategic stimulate of firms to develop capabilities. However, high or low EO can stimulate firm strategies such as a quality focus to develop capabilities to strategies (Rosenbusch et al., 2013; Terjesen et al., 2011). In other words, EO can influence how firm capabilities affect performance. Based on the discussion above, the following recommendations are given:

$>$ CSR development should be continually developed and coupled with entrepreneurship orientation.

$>$ It is necessary to nurture the CSR attitude of companies, which is more oriented on honesty (awareness to the quality improvement of stakeholders such as employees' life and their families, local communities and a broad society.

$>$ The willingness to take corporate social responsibility advantage is an important factor for entrepreneurs' success.

\section{Limitations and Future Research}

A limitation of this study is the generalizability due to the unique characteristic of the Department of Industrial Works (CSR-DIW) of Thailand. This research focused on the role of corporate social responsibility advantage and organizational performance to see how changing forms of corporate social responsibility advantage such as collaborative network and managerial innovation are being implemented in the firms.

The results are limited by this study is a cross-sectional design and using a single method of data collection. The sample size $(n=54)$ is relatively small, however, the data were all investigated, and appropriate measurements were taken through survey problems analysis such as reliability, validity and common method bias. Furthermore, the results of evaluating moderating effects indicated negative effects of the interaction between collaborative network and entrepreneurship orientation. For instance, the results might be useful to find level of entrepreneurship orientation which has the positive effects on organizational performance. All in all, the contribution and limitation together provide a fruitful area for further studies.

\section{References:}

Armstrong, S.J., Overton, T.S. 1977. Estimating Non-response Bias in Mail Survey. Journal of Marketing Research, 14, 396-420.

Blowfield, M., Murray, A. 2008. Corporate responsibility: A critical introduction. Oxford University Press.

Carroll, A.B., Shabana, K.M. 2010. The business case for corporate social responsibility: a review of concepts, research and practice. International Journal of Management Reviews, 12(1), 85-105.

Churchill, G.A., Iacobucci, D. 2002. Marketing Research: Methodological Foundation, eighth ed. South-Western, USA. 
Cohen, S., Kamarck, T., Mermelstein, R. 1983. A global measure of perceived stress. Journal of Health and Social Behavior, 24, 385-396.

Doty, D., Glick, W. 1998. Common method bias: Dose common methods variance really bias results? Organizational Research Methods, 1(4), 374-406.

Du, S., Vieira Jr, E.T. 2012. Striving for legitimacy through corporate social responsibility: insights from oil companies. Journal of Business Ethics, 110(4), 413-427.

European Commission. Directorate-General for Economic, Financial Affairs, and Economic Policy Committee of the European Communities. 2006. The impact of ageing on public expenditure: projections for the EU-25 Member States on pensions, healthcare, long-term care, education and unemployment transfers (2004-50). Office for Official Publications of the European Communities.

Gallego-Alvarez, I., Prado-Lorenzo, J.M., Garcia-Sanchez, I. 2011. Corporate social responsibility and innovation: a resource-based theory. Management Decision, 49(10), 1709-1727.

Husted, B.W., Allen, D.B. 2007. Strategic corporate social responsibility and value creation among large firms: lessons from Spanish experience. Long Range Planning, 40, 594610.

Huxham, C. 2003. Theorizing collaboration practice. Public Management Review, 5, 401-23.

Huxham, C., Vangen, S. 2005. Managing to Collaborate. Routledge, London.

Jalilvand, M.R., Nasrolahi Vosta, L., Kazemi Mahyari, H., Khazaei Pool, J. 2017. Social responsibility influence on customer trust in hotels: mediating effects of reputation and word-of-mouth. Tourism Review, 72(1), 1-14.

Kerlinger, F. 1986. Foundations of behavioral research. New York: Holt, Rinehart, and Winston.

Kim, E.E.K., Kang, J., Mattila, A.S. 2012. The impact of prevention versus promotion hope on CSR activities. International Journal of Hospitality Management, 31(1), 43-51.

López-Arceiz, F.J., Bellostas-Pérezgrueso, A.J., Moneva-Abadía, J.M., Rivera-Torres, M. P. 2018. The role of corporate governance and transparency in the generation of financial performance in socially responsible companies. Spanish Journal of Finance and Accounting/Revista Espa nola de Financiación y Contabilidad, 47(1), 44-80.

MacGregor, S.P., Fontrodona, J. 2008. Exploring the Fit between CSR and Innovation. Working Paper, University of Navarra, IESE Business School.

Mackey, A., Mackey, T., Barney, J.B. 2007. Corporate social responsibility and firm performance: investor preferences and corporate strategies. Academy of Management Review, 32(3), 817-835.

Martınez-Sanchez, A., Vela-Jimenez, M.J., Perez-Perez, M., de-Luis-Carnicer, P. 2009. Inter-organizational cooperation and environmental change: moderating effects between flexibility and innovation performance. British Journal of Management, 20(4), 537-561.

Miras Rodriguez, M.D.M., Carrasco Gallego, A., Escobar Perez, B. 2014. Corporate social responsibility and financial performance: a meta-analysis. Spanish Journal of Finance and Accounting-Revista Espanola De Financiacion Y Contabilida, 43(2), 193-215.

Mishra, S., Suar, D. 2010. Does corporate social responsibility influence firm performance of Indian companies? Journal of Business Ethics, 95(4), 571-601.

Nunnally, J.C. 1978. Psychometric Theory, second ed. McGraw-Hill, New York. 
Oeyono, J., Samy, M., Bampton, R. 2011. An examination of corporate social responsibility and financial performance: A study of the top 50 Indonesian listed corporations. Journal of Global esponsibility, 2(1), 100-112.

Rosenbusch, N., Rauch, A., Bausch, A. 2013. The mediating role of entrepreneurial orientation in the task environment-performance relationship: a meta-analysis. Journal of Management, 39(3), 633-659.

Terjesen, S., Patel, P.C., Covin, J.G. 2011. Alliance diversity, environmental context and the venture of manufacturing capabilities among new high technology ventures. Journal of Operations Management, 29, 105-115.

Tuan, L.T. 2015. From corporate social responsibility, through entrepreneurial orientation, to knowledge sharing. The Learning Organization, 22(2), 74-92.

Vilanova, M., Lozano. J.M., Arenas, D. 2009. Exploring the nature of the relationship between CSR and competitiveness. Journal of business Ethics, 87(1), 57-69. 